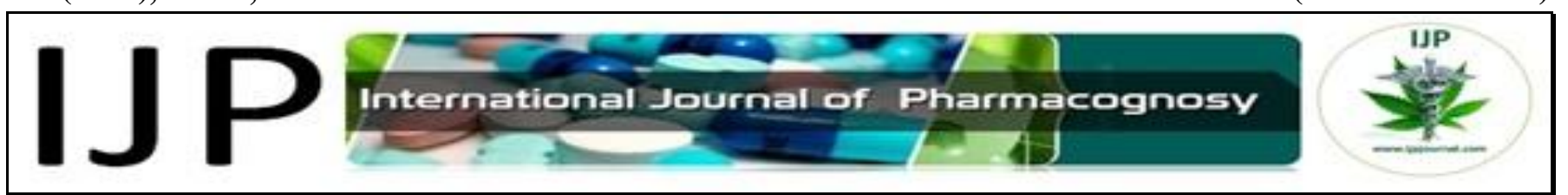

Received on 05 December 2015; received in revised form, 25 January 2016; accepted, 28 January 2016; published 29 February 2016

\title{
PHARMACOLOGICAL STUDIES OF METHANOLIC EXTRACTS OF SONCHUS ARVENSIS FROM KATHMANDU
}

Bhupendra Kumar Poudel *, Jagannath Prasad Sah, Shyam Raj Subedi, Mohan Prasad Amatya, Sadhana Amatya and Tirtha Maiya Shrestha

Institute of Medicine, Tribhuvan University, Kirtipur, Nepal.

Keywords:

Sonchus, Anti-Inflammatory, Motility, Locomotion, Extraction

Correspondence to Author: Bhupendra Kumar Poudel

Institute of Medicine, Tribhuvan University, Kirtipur, Nepal.

E-mail: poudel.bhupen@gmail.com

\begin{abstract}
Sonchus arvensis, a perennial sowthistle, is a common but underutilized species of Kathmandu, Nepal. Several uses like sedative, antioxidant and kidney stone eradicating properties have been identified till date, but a study on other pharmacological activities is not yet explored. Therefore, the plant was collected from Kathmandu; aerial parts of the plant were dried, crushed, and extracted using a Soxhlet apparatus. The methanolic extract was then concentrated for screening pharmacological effects. While comparing with the standards, the plant was found to possess potent anti-inflammatory activity and inhibitory effect in Gastro-Intestinal (GI) motility and locomotor activity in a dosedependent fashion. The plant, however, didn't show skeletal muscle relaxant activity as observed in the traction test and inclined plane test. Thus, it is concluded that the plant possesses strong phytochemicals having anti-inflammatory activity and inhibitory effect in locomotion and GI motility.
\end{abstract}

INTRODUCTION: In Nepal, the concept of ethnomedicine has developed since the late $19^{\text {th }}$ century (1885-1901 A.D). The Royal Nepal Academy published the first book "ChandraNighantu regarding medical plants in 1969. Majority of the population is still dependent on botanical medicines which indicates the importance of herbal medicines in the primary health care ${ }^{1,2}$. Sonchus arvensis, a vigorous herbaceous perennial plant with milky sap and creeping roots is abundantly available in $1000 \mathrm{~m}$ to $4100 \mathrm{~m}$ in range and grows in sandy, loamy or clayey soils ${ }^{3}$.

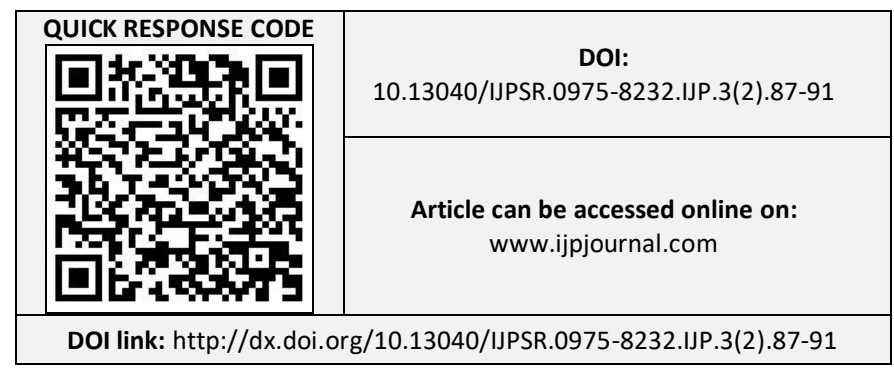

In many areas, this sow thistle is considered a noxious weed, as it becomes quickly in a wide range of conditions and it's wind-borne seeds allow them to spread rapidly ${ }^{4}$. Since, this plant is least explored, and there are only a few pharmacological studies, this study is done to lay a strong foundation for the future development of herbal medicines from this plant's methanolic extract.

\section{MATERIALS AND METHODS:}

Sample Preparation: Samples of the plant were collected from Nagarjuna Hill, Kathmandu, Nepal; the aerial parts were then dried, crushed, and extracted using a Soxhlet apparatus. Twenty grams of the powdered material was extracted with 200 $\mathrm{ml}$ volumes of petroleum ether, diethyl ether, methanol, and water, each in a stepwise manner. The extracts were concentrated and stored in the refrigerator. Only methanolic extract was used for pharmacological screening. Male albino mice (30 \pm $2.12 \mathrm{~g}$ ) were used for gastrointestinal motility, 
spontaneous locomotor activity, skeletal motility activity tests whereas male Wistar rats $(280 \pm 3.43$ g) for the anti-inflammatory test.

\section{Gastrointestinal Motility:}

Charcoal Meal Test: Mice were divided into 4 groups of 3 mice each; the first and second group were administered $500 \mathrm{mg} / \mathrm{kg}$ and $100 \mathrm{mg} / \mathrm{kg}$ of methanol extract made in normal saline solution intraperitoneally (i.p) respectively; the third group with atropine sulfate $(5 \mathrm{mg} / \mathrm{kg})$ i.p and a fourth group with control vehicle i.p. After 30 minutes all animals were fed with $1 \mathrm{ml}$ of the charcoal meal (animal charcoal $12 \mathrm{~g}$, tragacanth $2 \mathrm{~g}$, and water $130 \mathrm{ml}$ ) intragastrically with the aid of feeding needle. All the mice were killed after 30 minutes by inhalation of chloroform. The abdomen was opened, the intestine quickly isolated and the small intestine from the pylorus to caecum was cut by scissors and its length was measured by a ruler. The intestinal distance moved by the charcoal meal from pylorus was measured to calculate the percent of charcoal movement from pylorus to caecum as ${ }^{5}$.

$\%$ of Charcoal movement $=\frac{\text { Distance travelled by the charcoal meal }}{\text { Total length of the small intestine }} \mathrm{X} 100$

Spontaneous Locomotor Sctivity: ${ }^{6}$ Mice were divided into 5 groups, each consisting of 3 mice. The first group, serving as control, received i.p the vehicle only and the second group received i.p $5 \mathrm{mg} / \mathrm{kg}$ of Diazepam serving as a standard, while remaining groups were injected i.p with 125, 250 and $500 \mathrm{mg} / \mathrm{kg}$ of the methanolic extract i.p. After 30 minutes of administration of extract, each mouse was placed in an open square field $50 \times 50 \mathrm{~cm}$ surrounding and subdivided into 25 squares of $10 \times$ $10 \mathrm{~cm}$. The percentage inhibition in locomotion was calculated as:

$\%$ Inhibition $=100-\frac{\text { No. of squares crossed in test }}{\text { No. of squares crossed in control }} \times 100$

\section{Skeletal Muscle Activity:}

Traction Technique: ${ }^{7}$ Mice were divided into five groups of five mice in each. Each mouse of the first three groups was given methanolic extract i.p at the dose of $125 \mathrm{mg} / \mathrm{kg}, 250 \mathrm{mg} / \mathrm{kg}$ and $500 \mathrm{mg} / \mathrm{kg}$ respectively. One group received only distilled water as a control, and another group received diazepam at the dose of $5 \mathrm{mg} / \mathrm{kg}$ as a standard. After $30 \mathrm{~min}$, the capability of mice to touch the wire with at least one of the hind paws within 5 seconds was observed, and the formula calculated percentage failure:

$\%$ Failure $=\frac{\text { No. of mice failed to grasp the wire }}{\text { Total no. of mice }} \times 100$

\section{Skeletal Muscle Activity:}

Inclined Plane Test: ${ }^{7}$ Mice were divided into 5 groups of 4 mice each. The first group was given $125 \mathrm{mg} / \mathrm{kg}$, methanol extract, second group 250 $\mathrm{mg} / \mathrm{kg}$ methanol extract, third group $500 \mathrm{mg} / \mathrm{kg}$, fourth group diazepam $5 \mathrm{mg} / \mathrm{kg}$ and the fourth group, i.e. control group was given distilled water only i.p. After $30 \mathrm{~min}$ they were placed in the inclined plane $45^{\circ}$ for $2 \mathrm{~min}$ and their ability to remain at such inclination was noted.

The following formula calculated percentage failure:

$\%$ failure $=\frac{\text { no of mice failed to remain in the inclined plane }}{\text { total no of mice }} \times 100$

\section{Anti-Inflammatory Activity:}

Carrageenan Test: ${ }^{\mathbf{8}}$ It was studied in male Wistar rats $(280 \pm 3.43 \mathrm{~g})$ as per the method described by Winter et al. 1962. Rats were divided into 5 groups, each consisting of 3 rats. One group serving as control received i.p the vehicle (normal saline) only, and other group received i.p $100 \mathrm{mg} / \mathrm{kg}$ of Aspirin and $10 \mathrm{mg} / \mathrm{kg}$ Diclofenac serving as the standard, while remaining groups were injected i.p with $200 \mathrm{mg} / \mathrm{kg}$ and $400 \mathrm{mg} / \mathrm{kg}$ of the Methanol extract. One hour later each animal was injected with $0.1 \mathrm{ml}$ of $1 \%$ carrageenan suspension in normal saline into the sub-plantar region of the right hind paw. The diameter of the paw was measured in each rat by Vernier caliper before and $3 \mathrm{~h}$ after carrageenan injection. The width of edema was recorded as the difference between the two readings.

The percentage inhibition of edema was calculated as:

$\%$ Inhibition $=100-\frac{\text { Change in diameter of test group }}{\text { Change in diameter of control group }} \times 100$

RESULTS AND DISCUSSION: The extractive value for methanol extract was higher than for other extracts, and hence was used for pharmacological screening. Similar higher 
percentage yield was found for methanolic extract of $S$. arvensis than with other fractions ${ }^{9}$.

In this study, the extract decreased propulsion of the charcoal meal through the gastrointestinal tract of mice dose-dependently when compared with the control group. The $500 \mathrm{mg} / \mathrm{kg}$; intraperitoneal (IP) methanol and $5 \mathrm{mg} / \mathrm{kg}$; IP atropine had comparable inhibitory activity in intestinal motility Fig. 1. This reduction in gastrointestinal motility by methanol extract of $S$. arvensis may be due to antisecretory effects. The numerous phytochemicals like tannins, polyphenolic compounds, flavonoids, quercetin and other chemical compounds may be speculated for antimotility effect ${ }^{10}$. Hence, this activity of the plant may be useful in the treatment of diarrhoea as an antimotility agent.

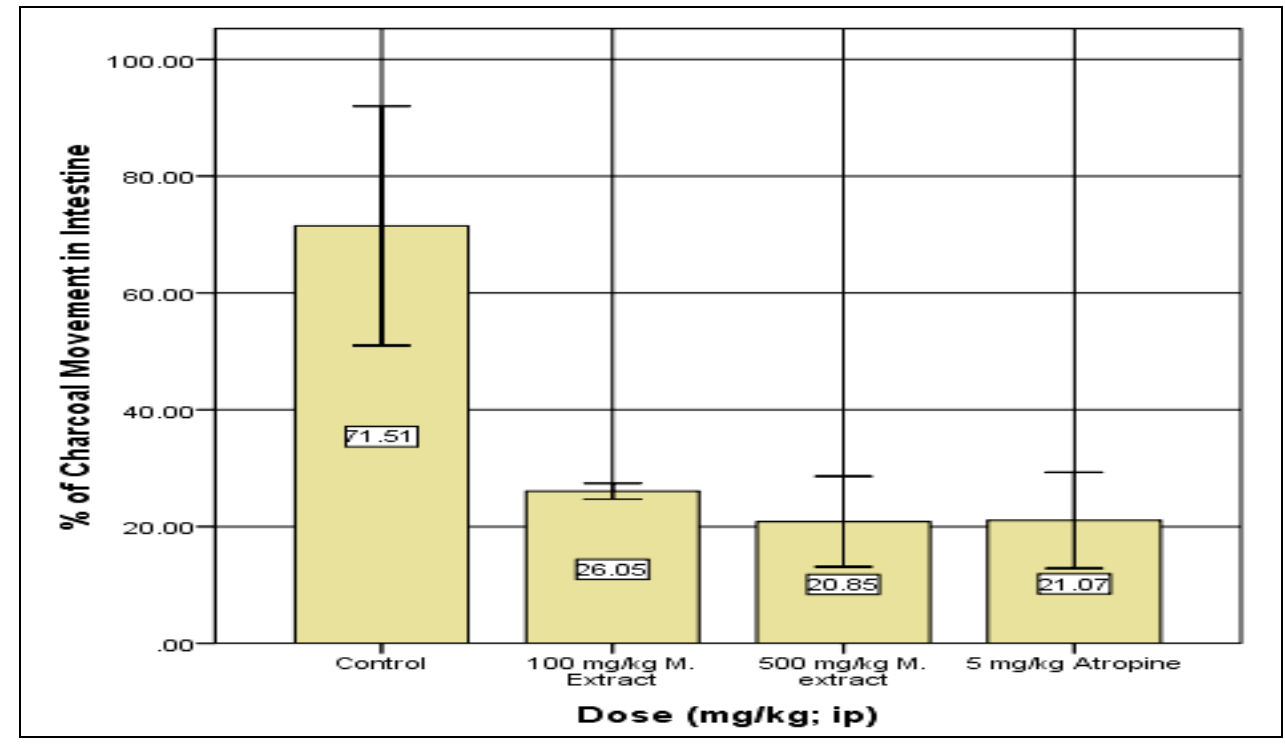

FIG. 1: EFFECT OF METHANOL EXTRACT ON INTESTINAL MOTILITY

Similarly, methanol extract significantly inhibited locomotor activity on mice in dose-dependent fashion indicating antidepressant property Fig. 2.
Therefore, a standardized S. arvensis extract or its purified constituents could be of potential interest for the GI motility disorders.

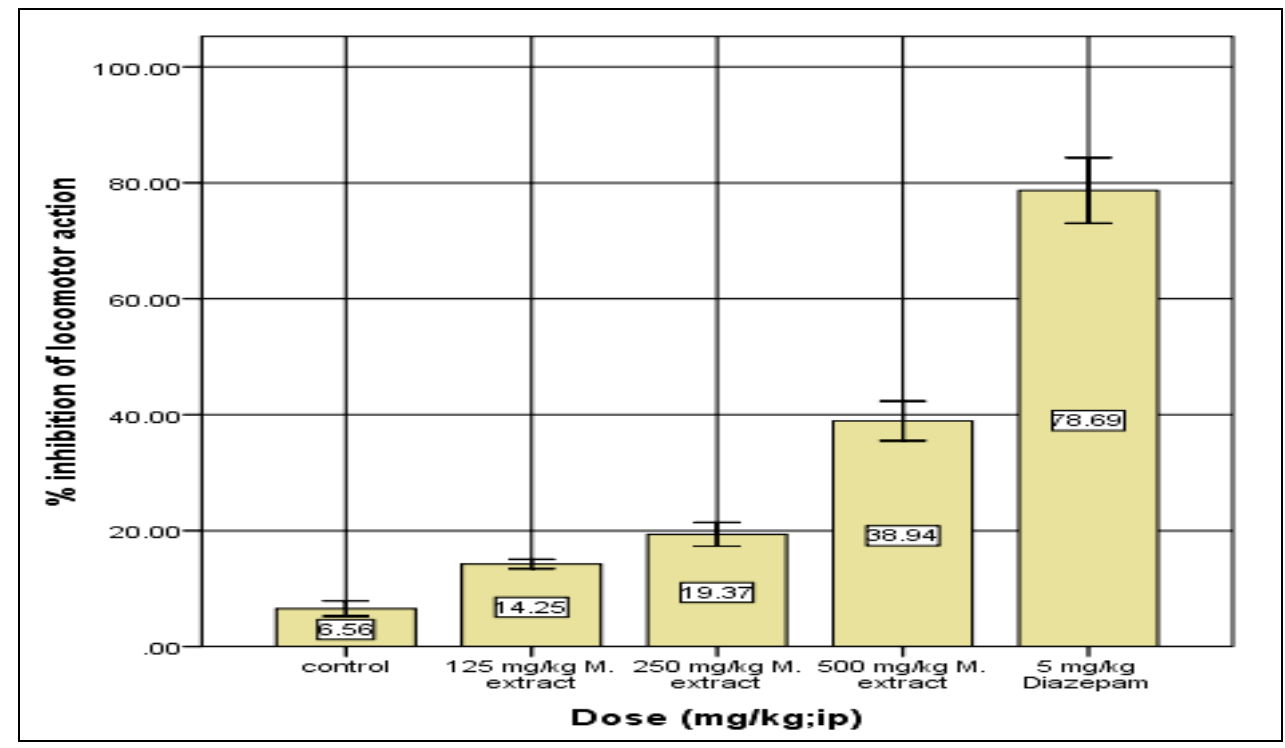

FIG. 2: EFFECT OF METHANOL EXTRACT ON LOCOMOTOR ACTIVITY

The traction test and inclined plane test revealed that the methanol extract didn't possess skeletal muscle relaxant activity Table 1 and 2. 
TABLE 1: EFFECT OF METHANOL EXTRACT OF ON SKELETAL MUSCLE OF MICE BY TRACTION TEST

\begin{tabular}{cccc}
\hline Treatment & Dose $(\mathbf{m g} / \mathbf{k g} ; \mathbf{I P})$ & No. of mice failed to grasp the wire & \% failure \\
\hline Control & - & 0 & 0 \\
M. Extract & 125 & 0 & 0 \\
M. Extract & 250 & 0 & 0 \\
M. Extract & 500 & 0 & 0 \\
Diazepam & 5 & 4 & $100 \%$ \\
\hline
\end{tabular}

TABLE 2: EFFECT OF METHANOL EXTRACT ON SKELETAL MUSCLE OF MICE BY INCLINED PLANE TEST

\begin{tabular}{cccc}
\hline Treatment & Dose (mg/kg; IP) & Animal falling after treatment & \% failure \\
\hline Control & - & 0 & 0 \\
M. Extract & 125 & 0 & $0 \%$ \\
M. Extract & 250 & 0 & $0 \%$ \\
M. Extract & 500 & 0 & $0 \%$ \\
Standard (Diazepam) & 5 & 4 & $100 \%$ \\
\hline
\end{tabular}

Further, methanol extract inhibited carrageenaninduced acute paw edema in dose-dependent manner indicating anti-inflammatory activity. 400 $\mathrm{mg} / \mathrm{kg}$; ip methanol extract had higher antiinflammatory activity than $10 \mathrm{mg} / \mathrm{kg}$; ip diclofenac Fig. 3. Carrageenan releases prostaglandins ${ }^{11}$ and inflammation occurs because of a proteolytic process with formation of kinin-like mediator(s) ${ }^{12}$.
S. arvensis contains various compounds palmitic acid, $\beta$-sitosterol, daucosterol, quercetin, apigenin7-O- $\beta$-glucopyranoside, luteolin $-7-O-\beta-\mathrm{D}-$ glucopyranoside, quercetin $-3-O-\beta-\mathrm{D}-$ glucopyranoside and rutin ${ }^{13}$ which might have produced above pharmacological effects. However, further studies are required to isolate the significant bioactive constituents and to verify the findings.

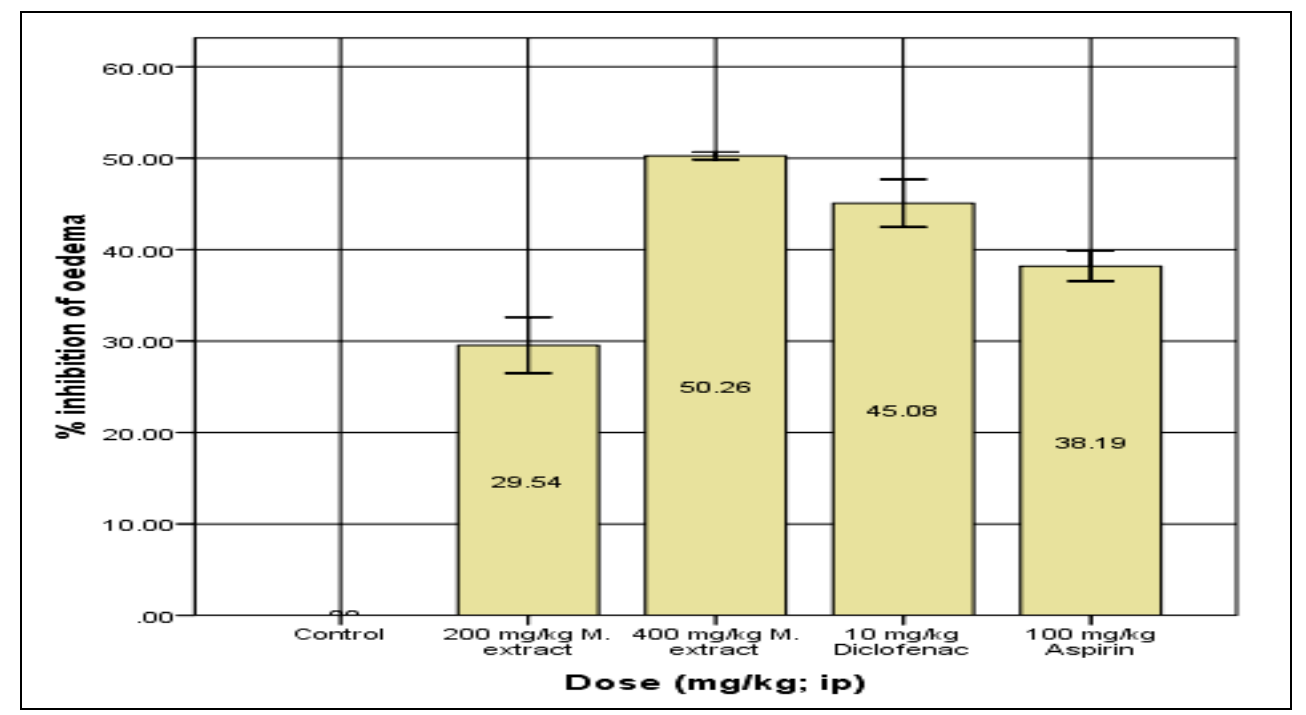

FIG. 3: EFFECT OF METHANOL EXTRACT ON ANTI-INFLAMMATORY ACTIVITY

CONCLUSION: This study revealed significant anti-inflammatory, inhibitory activity on both gastrointestinal and locomotor activity. The investigation, however, showed no skeletal muscle activity. It may, therefore, be concluded from this study that the plant possessed constituents that revealed above pharmacological properties which may generate lead molecules for the development of newer drugs. However, to reach any conclusive decision a detailed phytochemical study for isolation, purification, identification, and characterization of the compound and biological studies with the exact mechanism of action responsible for the particular activity, is necessary. Hence, further scientific investigation and specific studies are highly recommended for better evaluation of the potential effectiveness of the plant.

ACKNOWLEDGEMENT: The authors are thankful to the Department of Pharmacy, Institute of Medicine, Tribhuvan University for providing laboratory and laboratory materials to conduct experiments. 


\section{CONFLICT OF INTEREST: Nil}

\section{REFERENCES:}

1. Rajbhandari KR: Ethnobotany of Nepal. Kathmandu: Ethnobotanical Society of Nepal (ESON) 2001: 189.

2. Amatya MP, Srivastava DL, Shakya KS, Pradhan NB, Karmacharya K, Shrestha UK and Ranjit R: Phytochemical and Pharmacological studies of Osbeckia stellata Buch.-Ham. Ex D. Don. Plant Resources-Bull Dept Pl Res 2009; 31: 56-63.

3. Holm L, Doll J, Holm E, Pancho J and Herberger J: World weeds: natural histories and distribution. John Wiley \& Sons 1997: 1129.

4. Sonchus. Australian Plant Name Index (APNI), IBIS database. Centre for Plant Biodiversity Research, Australian Government, Canberra. http://www.anbg.gov. au/cgi-bin/apni?TAXON_NAME=SONCUS. Retrieved 2015-7-2

5. Rouf ASS, Islam MS and Rahman MT: Evaluation of antidiarrhoeal activity Rumex maritimus root. Journal of Ethnopharmacology 2003; 84: 307-310.

6. Kulkarni SK: Hand Book of Experimental Pharmacology, $2^{\text {nd }}$ ed. India: Vallabh Prakashan 2000: 43-56.

7. Chattopadhyay DP, Arunachalam G, Mandal SC, Bhadra $\mathrm{R}$ and Mandal $\mathrm{AB}$ : CNS activity of the methanol extracts of Mallotus peltatus (geist) Muell Arg. leaf: An ethnomedicine of onge. Journal of Ethnopharmacology 2003; 85: 99-105.

8. Arumozhi DK, Veeranjaneyulu A, Badhankar SL and Arora SK: Pharmacological investigations of sapindus trifoliatus in various in-vitro and in-vivo models of inflammation. Indian Journal of Pharmacology 2005; 37: 96-102.

9. Khan RA: Evaluation of flavonoids and diverse antioxidant activities of Sonchus arvensis. Chemical Central Journal 2012; 6: 126.

10. Ezekwesili JO, Nkemdilim UU and Okeke CU: Mechanism of an antidiarrhoeal effect of ethanolic extract of Psidium guajava leaves. Biokemistri, 2010; 22(2): 201.

11. Winter CA, Risley EA and Nuss GW: Carrageenininduced edema in hind paw of the rat as an assay for antiinflammatory drugs. Proceedings of the Society of Experimental Biology and Medicine 1962; 111: 544-7. [Merck Institute for Therapeutic Research, WestPoint, PA]

12. Rosa MD and Sorrentino L: The mechanism of the inflammatory effect of carrageenin. European Journal of Pharmacology 1968; 340-342.

13. Jiang L, Qiang-Qiang $\mathrm{Y}$ and Yan-Ying X: Study on chemical constituents of Sonchus arvensis L. Food and Drug 2009; 11(3): 27-29.

How to cite this article:

Poudel BK, Sah JP, Subedi SR, Amatya MP, Amatya S and Shrestha TM: Pharmacological Studies of Methanolic Extracts of Sonchus Arvensis from Kathmandu. Int J Pharmacognosy 2016; 3(2): 87-91. doi: 10.13040/IJPSR.0975-8232.3(2).87-91.

This Journal licensed under a Creative Commons Attribution-Non-commercial-Share Alike 3.0 Unported License.

This article can be downloaded to ANDROID OS based mobile. Scan QR Code using Code/Bar Scanner from your mobile. (Scanners are available on Google Playstore) 